\title{
Twelve Monkeys, the Kassandra dilemma and innovation diffusion: transdisciplinary lessons for animal and environmental activism
}

\author{
SARAH RUTHERFORD SMITH
}

\begin{abstract}
Animal activists and environmental activists believe that the world and its inhabitants face devastating consequences in the future if behaviour towards and the treatment of animals and the environment do not change. However, despite their predictions many people are not swayed to change their behaviour. This article suggests that these activists experience what is known as Kassandra's dilemma; the conundrum of knowing what the future holds but being unable to prevent events from happening. Drawing on the film, Twelve Monkeys and Greek mythology this article explores this mythological dilemma and explains how this dilemma is a lived experience for activists. The article suggests that activists can resolve Kassandra's dilemma by taking a transdisciplinary approach towards animal and environmental activism. Thus, in order to escape Kassandra's dilemma the article suggests that animal and environmental activists require transdisciplinary knowledge; knowledge of the actual and potential harm done to animals and the environment and how this can be prevented as well as knowledge on how to successfully convey this knowledge to others. The article highlights innovation diffusion theory as an example of the type of transdisciplinary knowledge that could assist in escaping from Kassandra's dilemma and in order to better advocate on behalf of animals and the environment.
\end{abstract}

$$
\begin{array}{r}
5 \text { billion people will die from a deadly virus in } \\
\text { 1997. . . The survivors will abandon the face } \\
\text { of the planet. Once again the animals will rule the world. } \\
\text { Twelve Monkeys }{ }^{1}
\end{array}
$$

\section{Introduction}

Many animal and environmental activists face what is known as Kassandra's dilemma. ${ }^{2}$ These activists feel that the current treatment of animals and the environment by human beings

Sarah Rutherford Smith, LLB (Wits) LLM (Unisa), is a senior lecturer Department of Jurisprudence, College of Law, Unisa.

1 Twelve Monkeys (1995) (Directed by Terry Gilliam (C) Universal Pictures), inspired by La Jetee.

2 Kassandra's dilemma, also called the Kassandra complex, is found in the Greek tragedy Agamemnon and will be discussed in more detail at 2 2. Eschylus Agamemnon (translated from the Greek by T Medwin) (William Pickering London 1832). In many modern texts Kassandra is called Cassandra, but for the sake of authenticity the classical spelling, Kassandra will be used in this text except when Cassandra has been used in a direct quote. 
could have devastating consequences for our planet and its inhabitants. ${ }^{3}$ However, despite predictions of global warming, rising ocean levels, permanent environmental damage, extinction of numerous species, new mutating viruses (whether caused by the close proximity of humans to animals, eating infected animal flesh or intensive livestock farming practices among many other causes of virus transmission between species $)^{4}$ few people are swayed by the concerns of activists to change their behaviour. ${ }^{5}$

Drawing on the story of Kassandra from the film, Twelve Monkeys and from the original source in Greek mythology, Kassandra's dilemma is the mythological condition where a person is armed with foreknowledge but is unable to convince others to act on that knowledge. This article proposes that both animal activists and environmental activists are

Consequences such as human-caused global warming or virus transmission between species. There is much debate about whether these are real threats to human survival. However, for the purposes of this article it is assumed that climate change, global warming or virus transmission between species (amongst numerous other animal and environmental concerns) are genuine threats to human beings' survival and / or way of life. However, for a different view on these types of threats see Lomborg B "The Truth about the environment" http://www.economist.com/node/718860 (Date of use 25 June 2013); McIntyre S and McKitrick R "Corrections to the Mann et al (1998) Proxy Data Base and Northern Hemisphere Average Temperature Series" 2003 (14) 6 Energy and Environment 751-772; William H "The Truth about Greenhouse Gases" The Global Warming Policy Foundation Briefing Paper no 32011 http://www.thegwpf.org/images/stories/gwpf-reports/happerthe truth_about_greenhouse_gases.pdf (Date of use: 12 June 2013); Ridely M "Scientific Heresy" Angus Millar Lecture of the Royal Society of the Arts Edinburgh, 31 October 2011 http://au.agwscam.com/pdf/Scientific\%20Heresy\%20-\%20Matt\%20Ridley.pdf (Date of use: 12 June 2013) and for a general overview see Montford AW The Hockey Stick Illusion (Stacey International London 2010) and McIntyre S and McKitrick R The IPCC, the "Hockey Stick" Curve, and the Illusion of Experience (George C Marshall Institute Washington 2003). For sources disputing global warming sceptics see Union of Concerned Scientists "Global warming contrarians" http://www.ucsusa.org/global_warming/science_and_impacts/global_warming_contrarians/ (Date of use: 17 July 2012) and the sources therein.

The animal origins of human viruses are discussed in multiple sources, for instance Ter Meulen J et al "Hunting of Peridomestic Rodents and Consumption of Their Meat as Possible Risk Factors for Rodent-to-Human Transmission of Lassa Virus in the Republic of Guinea" American Journal of Tropical Medicine and Hygiene December 1996 (55) 661-666 discuss the transmission of the Lassa virus from rodents to human through consumption; Webster RG "Influenza virus: transmission between species and relevance to emergence of the next human pandemic" 1997 Viral Zoonoses and Food of Animal Origin 105-113 discuss the transmission of the Influenza A virus from wild aquatic birds to domestic poultry and to mammals (including humans); Garten RJ et al "Antigenic and Genetic Characteristics of Swine-Origin 2009 A(H1N1) Influenza Viruses Circulating in Humans" 2009 (325) 5937 Science 197-201 discuss the transmission of the H1N1 virus from swines to humans; and Tei $\mathrm{S}$ et al "Zoonotic transmission of hepatitis $\mathrm{E}$ virus from deer to human beings" The Lancet 2003 (362) 9381 371-373 discuss the transfer of the hepatitis E virus from deer to humans. See also Grace D "Zoonoses: The lethal gifts of Livestock" http://www.ilri.org/ilrinews/index.php/archives/9929 (Date of use: 14 June 2013). 
confronted with this dilemma in their quest to improve the treatment of and, in the worst case scenario, save animals and the environment.

This article does not set out to confirm the beliefs of animal and environmental activists; many of the concerns they raise are debatable. ${ }^{6}$ Instead this article is an effort to understand why activists are not succeeding in conveying their beliefs or in converting people to their beliefs. The article suggests that activists could expand their knowledge areas beyond the usual disciplines of philosophy and the natural sciences to borrow from other disciplines such as communication and marketing in order to successfully convey their beliefs. Thus the article recommends a transdisciplinary approach to animal and environmental activism. Indeed, transdisciplinary research promotes addressing problems between disciplines, across disciplines and beyond disciplines and thus ensures a fuller understanding of the world and its problems. ${ }^{7}$ Transdisciplinary research is intended to, 'solve problems that are complex and multi-dimensional, particularly problems ... that involve an interface of human and natural systems. The founding idea here is that society is facing problems manifest in the real world that are complex, multi-dimensional and not confined by the boundaries of a single disciplinary framework. ${ }^{8}$ Consequently, the article suggests that the problems that animal and environmental activists face in conveying their beliefs can be solved through transdisciplinary research and knowledge.

The article does not wish to conflate the concerns of animal activists with environmental activists and vice versa. However, when contemplating the future existence of the human race, animal activism and environmental activism often share the same interests. For instance, many animal activists and some environmental activists promote a vegan lifestyle because the vegan lifestyle is beneficial to animals as well as the environment. ${ }^{9}$ Consequently, in some instances to advocate on behalf of animals often amounts to advocating on behalf of the

$6 \quad$ As discussed in fn 3 see Lomborg http://www.economist.com/node/718860 (Date of use 25 June 2013); McIntyre and McKitrick 2003 Energy and Environment 751-772; McIntyre and McKitrick 2003 The IPCC, the "Hockey Stick" Curve, and the Illusion of Experience; Montford 2010; William 2011 http://www.thegwpf.org/images/stories/gwpf-reports/happerthe_truth_about_greenhouse_gases.pdf (Date of use 12 June 2013); Ridely 2011 http://au.agwscam.com/pdf/Scientific\%20Heresy\%20-\%20Matt\%20Ridley.pdf (Date of use 12 June 2013).

$7 \quad$ Polimeni JM “Transdisciplinary research: moving forward” 2006 (1) 1 International Journal of Transdisciplinary Research 2.

8 Wickson F, Carew AL and Russell AW "Transdisciplinary research: characteristics, quandaries and quality" 2006 (38) Futures 1048.

The vegan lifestyle is one area where animal and environmental activist's interests overlap; both types of activists have an interest in promoting a vegan lifestyle. Environmental activists may promote a vegan lifestyle because of the environmental benefits of following a vegan diet. Steinfeld $\mathrm{H}$ et al Livestock's Long Shadow. Environmental Issues and Options (Food and Agricultural Organization of the United Nations Rome 2009) 4- 6; 79 - 114, 125 - 169; 181 - 215. Because veganism is an area where animal and environmental activism collaborate it will be used as an example throughout the article. Another example of overlap is poaching where the animal activist is concerned about the animal itself, whereas an environmental activist may be concerned about survival of the species and biodiversity. See Brodie JF et al "Bushmeat poaching reduces the seed dispersal and population growth rate of a mammaldispersed tree" 2009 (19) 4 Ecological Applications 854 - 863 for an example of how poaching can effect biodiversity. 
environment and the two forms of activism become interrelated. ${ }^{10}$ Thus, for the purpose of this article, the concerns of animal activists and environmental activists will be considered together.

This article will utilize the film, Twelve Monkeys as a platform from which to introduce Kassandra's dilemma and to discuss the link between the dilemma and animal and environmental activism. ${ }^{11}$ Thus, the article begins with a summary of the film, followed by a more detailed examination of the (film) themes of animal and environmental activism and thereafter the Kassandra dilemma. Then the article will highlight how the Kassandra dilemma is a real consequence for animal and environmental activists. Finally, the article will draw on the concept of innovation diffusion (from communication studies) to suggest one transdisciplinary method for escaping Kassandra's dilemma. ${ }^{12}$

\section{Twelve Monkeys}

The film Twelve Monkeys revolves around a virus which has destroyed ninety nine percent of the human population. The surviving one percent escapes the virus by beginning a colony beneath the Earth's surface. Astrophysicists living in this underground colony begin to experiment with time travel and send the protagonist James Cole (played by Bruce Willis) back in time to before the release of the virus. Cole is sent to find an animal rights group called the Army of the Twelve Monkeys who are believed to have released the virus. ${ }^{13} \mathrm{He}$ is tasked with finding out more information about the Army of the Twelve Monkeys and the virus as well as to try and stop them from releasing the virus. But in this time (the past) Cole's predictions of the future are viewed as a sign of mental illness. He is institutionalised under the treatment of psychiatrist Dr Railly (played by Madeleine Stowe). ${ }^{14}$ Dr Railly proposes that Cole suffers from a mental illness known as the Kassandra complex. ${ }^{15}$ She suggests that Cole suffers from the delusional belief that he knows what is going to happen in the future. Whilst Dr Railly does not believe Cole's predictions of the future she accepts that he believes them and that for him the delusions are real.

10 Regan $\mathrm{T}$ "The Philosophy of Animal Rights" http://www. cultureandanimals.org/pop1.html\#a9 (Date of use: 17 July 2013). For more on the intersection between animal activism and environmental activism see Shapiro K "The Caring Sleuth: Portrait of an Animal Rights Activist" 1994 (2) 2 Society and Animals 145 - 165150 151; Herzog HA "The movement is My Life: The Psychology of Animal Rights Activism" 1993 (49) 1 Journal of Social Issues 103 -119 111; Lawrence EA "Conflicting Ideologies: Views of Animal Rights Advocates and their Opponents" 1994 (2) 2 Society and Animals 175 - 190 175.

$11 \quad$ Twelve Monkeys 1995.

This article is not intended to be a study of diffusion innovation theory; rather it is intended to highlight the potential benefits of transdisciplinary research and applications.

Ruben 1998 Rethinking Marxism: A Journal of Economics, Culture and Society 106 -123 107. See also Cohen AJJ "12 Monkeys, Vertigo and La Jetée. Postmodern Mythologies and Cult Films" 2003 (1) 1 New Review of Film and Television Studies149-164.

14 Anon "Synopsis for Twelve Monkeys" http://www.imdb.com/title/tt0114746/synopsis (Date of use: 13 May 2013). exists for the purposes of the movie. 
During his time in the psychiatric hospital Cole has a conversation with fellow patient, Jeffery Goines (played by Brad Pitt) who the audience later finds out is the leader of the Army of the Twelve Monkeys. During this conversation between Cole and Goines, Goines draws attention to images of animal vivisection which are being shown on the hospital's television and says, "Torture! Experiments! We're all monkeys." ${ }^{16}$ And Cole exclaims, "They hurt you!" thinking that Goines was being used as a test subject by the hospital's medical staff. ${ }^{17}$ Goines responds pointing to the vivisection images, "Not as bad as what they're doing to the Easter Bunny." 18 Cole looks at the television which shows a scientist performing a Draize test ${ }^{19}$ on a rabbit and, thinking about the coming biological genocide, says, "Look at them. They're just askin' for it. Maybe the human race deserves to be wiped out." ${ }^{20}$ Famously, Brad Pitt's character responds, "Wiping out the human race? It's a great idea. It's great. But more of a long-term thing." 21

The film continues with Cole traveling backwards and forwards in time gathering and reporting information to the astrophysicists of the future. On Cole's final trip(s) to the past Dr Railly becomes convinced that there is truth in his predictions and together they set out to find the Army of the Twelve Monkeys. They discover that it is not the Army of the Twelve Monkeys who is going to be responsible for releasing the virus. Instead, it is a renowned virologist (and vivisectionist) Dr Peters (played by David Morse) who intends to release the virus. Cole attempts to prevent Dr Peters from releasing the virus but he is shot and the film ends leaving the question of whether the world will be saved unanswered. ${ }^{22}$

16 Peoples D and Peoples J "Twelve Monkeys: An Original Screen Play" http://www.imsdb.com/scripts/12-Monkeys.html (Date of use: 4 July 2013).

17 Peoples and Peoples http://www.imsdb.com/scripts/12-Monkeys.html (Date of use: 4 July 2013).

18 Peoples and Peoples http://www.imsdb.com/scripts/12-Monkeys.html (Date of use: 4 July 2013).

19 The Draize test requires a substance to be applied to either the skin or the eye of a restrained animal, the substance is then left for a set period before it is washed off. The test is performed to record the effects of exposure to the substance. Carbone L What Animals Want: Expertise and Advocacy in Laboratory Animal Welfare Policy (Oxford University Press Oxford 2004) 24, 63.

Peoples and Peoples http://www.imsdb.com/scripts/12-Monkeys.html (Date of use: 4 July 2013).

21 Peoples and Peoples http://www.imsdb.com/scripts/12-Monkeys.html (Date of use: 4 July 2013).

Anon "http://www.imdb.com/title/tt0114746/synopsis (Date of use: 13 May 2013). Cleverly the movie does not suffer from the grandfather paradox i.e. if Cole is killed how is still alive in the future to be sent back in time? In the past Cole is alive as both the time traveller and as a young child who will survive the biological genocide and grow up to be the time travelling Cole. For more on the grandfather paradox see Riggs PJ "The principal paradox of time travel"1997 (10) 1 Ratio 48 - 64; Smith NJJ "The problems of backwards time travel" 1998 (22) 4 Endeavour $156-158$. 


\section{Animal and environmental activism within Trelve Monkeys}

Many themes are presented in the film, but only the themes of animal and environmental activism and the Kassandra complex will be explored in this article. It will be considered how these themes interact in the film and how they are relevant for activists today.

\section{Animal activism}

Animal activism and, to a lesser extent, environmental activism are constant themes of the film. In regard to animal activism, along with the images of vivisection shown on the hospital television (discussed above) the audience witnesses numerous visuals. Towards the end of the film the Army of the Twelve Monkeys kidnaps a Nobel prize winning virologist and releases zoo animals in a protest against laboratories (owned by the virologist) which test on animals. Moreover, Dr Peters, who releases the virus, works in these vivisection laboratories and viewers see him working alongside monkeys in cages and hear animal calls in the background noise of the laboratory. Further, it is implicitly suggested that participation in and exposure to vivisection may be one of the reasons why Dr Peters has become disillusioned with the world. Viewers also see the inside of the Army's headquarters which is pasted top to bottom with animal rights images and literature. Added to these more prominent images viewers are consistently exposed to animal images in the background of the film, for instance cartoon animals such as Woody Woodpecker appear on television, images of animals are shown on clothing, stuffed toy animals, a scene from the Marx Brothers' film, Monkey Business is shown, ${ }^{23}$ advertisements using animals are shown, animal rights bumper stickers, animal activist protests, animal statues, stuffed animals, newspaper articles concerning animals and animal rights issues, service animals, animal carvings, bed linen with animal pictures on it, paintings of animals and a scene from Alfred Hitchcock's film, The Birds is shown. ${ }^{24}$ And, once the virus is released and the human race is erased from the Earth's surface the viewers see nature reclaiming the urbanised areas of the earth; where there had been a stuffed bear there is a live bear, where there was a statue there is a lion and so on.

Whether prominent or in the background of the film the audience is consistently exposed to animals and animal activism issues, and viewers are constantly reminded of how animals have been constructed or employed for human use. ${ }^{25}$

\section{Environmental activism}

Environmental activism is a far less prominent theme of the film but nevertheless a constant theme. Dr Peters voices concern about atomic weaponry, over population, pollution and

$23 \quad$ Monkey Business (1931) (Directed by Norman Z McLeod (P) Paramount Studios). It is only the title of this film that highlights animals, unlike the other references to Alfred Hitchcock's Vertigo and The Birds (to be discussed below) Monkey Business does not share thematic elements with Twelve Monkeys. Vertigo (1958) (Directed by Alfred Hitchcock (C) Paramount Pictures); The Birds (1963) (directed by Alfred Hitchcock (C) Universal Pictures).

The Birds 196. The Birds revolves around a town which is attacked by flocks of birds. In one scene the lead character comments in regard to the bird attacks, ' $[\mathrm{m}]$ aybe they're all protecting the species. Maybe they're tired of being shot at and roasted in ovens'. Hunter E "The Birds" http://www.imsdb.com/scripts/Birds,-The.html (Date of use: 8 July 2013). 
general environmental degradation. ${ }^{26}$ Furthermore, numerous times throughout the film Cole comments on the natural environment - the light, the air, the water; and to an extent the film is a commentary on urbanization and development. ${ }^{27}$ Once the virus is released the audience is witness to nature claiming back urbanised and built-up areas; for instance, the film shows Cole and Railly shopping in Philadelphia and then in the future the audience sees the same shop falling into ruins, the roof is decayed, the shop floor is exposed to the elements and a flock of pigeons are roosting in the ruins.

The film causes its audience to question human treatment of animals and the environment; and whether current human behaviour might lead to the destruction of the world as we know it. Ultimately the viewer must contemplate the future of the human race and ponder whether the future for humans will amount to survival or extinction, as a character in the film suggests, '[y] ou might say...we're the next endangered species...human beings! ${ }^{28}$

\section{Kassandra's dilemma or the Kassandra complex}

As previously stated, the Kassandra complex (as proposed by Dr Railly) is a mental illness invented for the purpose of the film. The idea for the Kassandra complex can be found in Greek mythology.

\section{Greek mythology}

In Greek mythology Kassandra is the daughter of King Priam and Queen Hekaba of Troy. ${ }^{29}$ Kassandra was so beautiful that the god Apollo (who among other things is the god of prophecy) granted Kassandra the gift of prophecy. ${ }^{30}$ But when Apollo made sexual advances towards Kassandra she spurned him. ${ }^{31}$ To revenge this rejection Apollo cursed Kassandra by ordaining that her prophecies would never be believed. ${ }^{32}$ Thus Kassandra is able to predict the future but she is unable to convince anyone to act on her warnings, she suffers 'the agony of foreknowledge combined with the impotence to do anything about it. ${ }^{33}$ For instance, Kassandra prophesised the fall of Troy but nobody believed her and shortly after Troy fell to the Greek king Agamemnon. ${ }^{34}$ Following the fall of Troy Kassandra is taken as a concubine by the conquering King Agamemnon. And she travels with Agamemnon to his home in

26 Peoples and Peoples http://www.imsdb.com/scripts/12-Monkeys.html (Date of use: 4 July 2013).

Ruben 1998 Rethinking Marxism: A Journal of Economics, Culture and Society 106 -123 115 .

Peoples and Peoples http://www.imsdb.com/scripts/12-Monkeys.html (Date of use: 4 July 2013).

Anon "Cassandra" Encyclopadia Britannica. Encyclopadia Britannica Online Academic Edition http://www.britannica.com/EBchecked/topic/98088/Cassandra (Date of Use 25 June 2013). Graf F Apollo (Routledge, Taylor and Francis Group New York 2009) 52.

Graf Apollo 76; Hard R The Routledge Handbook of Greek Mythology (Routledge, Taylor and Francis Group New York 2004) 154.

Peoples and Peoples http://www.imsdb.com/scripts/12-Monkeys.html (Date of use: 4 July 2013).

Hard

The Routledge

Handbook of Greek Mythology

154; Anon http://www.britannica.com/EBchecked/topic/98088/Cassandra (Date of Use 25 June 2013). 
Mycenae. ${ }^{35}$ Upon reaching Mycenae, Kassandra warns Agamemnon against his adulterous wife and her lover who intend to murder Agamemnon and Kassandra. ${ }^{36}$ But her curse endures and Agamemnon does not believe her warnings, consequently both he and Kassandra are killed by the queen's paramour.

Kassandra's life appears tragic, she is cursed with visions of death, which are terrifying for her, and she beseeches her audience to see what she sees, to believe what she believes, to act on her prophecy. ${ }^{37}$ She suffers for her visions but, despite her sacrifice, her words fall on deaf ears. ${ }^{38}$ Instead of being respected by her people for her abilities she is derided. This lack of recognition and affirmation erodes her confidence in her visions and she becomes insecure and anxious. ${ }^{39}$ She feels responsible for what has happened because she knew it would happen but was unable to persuade people to believe her and so could not prevent it; she predicted the sacking of Troy but couldn't prevent it and so she experiences feelings of responsibility and guilt for the destruction of her father's kingdom. ${ }^{40}$ Ultimately Kassandra foresees her own demise and is either too exhausted to try harder to prevent it or has accepted a fate that she is powerless to prevent; she realises that her life has been wasted, that it has been pointless, "thus must end my days [.] What have been, few and evil, yet too many."

\section{Kassandra's dilemma in Twelve Monkeys}

In Twelve Monkeys Kassandra's tragedy is Cole's tragedy. Cole knows what the future holds but cannot convince anyone (except, eventually, Dr Railly) to act on what he is telling them and ultimately he is killed trying to prevent what he knows is going to happen from happening. ${ }^{42}$ Like Kassandra Cole becomes confused, anxious and insecure from living in two different realities; as Cole says, "I want to become... become a whole person again. ... I want the future to be unknown." ${ }^{43}$

However, Cole is not the only character in the film caught up in Kassandra's tragedy; instead the themes of prophecy and the inability to change the future are relevant throughout the film. Like the themes of animal and environmental activism, references to the Kassandra complex are infused throughout the film. For instance, reference is made to Dr Ignaz Phillip Semmelweis, a Hungarian doctor who proposed hand washing as a way of combatting

$35 \quad$ Hard The Routledge Handbook of Greek Mythology 479.

36 Æschylus 1832 Agamemnon $49-50$.

37 Æschylus 1832 Agamemnon 58 -59.

Æschylus 1832 Agamemnon 55.

39 Shamas LA "Understanding the Myth: Why Cassandra Must Not be Silenced" http://www.ontheissuesmagazine.com/cafe2/article/163 (Date of use: 13 May 2013). Hard The Routledge Handbook of Greek Mythology 154.

$41 \quad$ Eschylus 1832Agamemnon) 61.

42 Throughout the movie Cole is traumatised by dreams (or rather memories) of himself dying and by the time the movie reaches its climax Cole knows that he will be killed trying to prevent the virus from being released. Thus, like Kassandra, Cole has accepted his fate that he will die and that there is nothing he can do to prevent it.

43 Peoples and Peoples http://www.imsdb.com/scripts/12-Monkeys.html (Date of use: 4 July 2013). 
puerperal fever. ${ }^{44}$ Dr Semmelweis' idea was not recognised by the medical community and he was ridiculed for suggesting that a lack of hand washing caused the transmission of the virus. Dr Semmelweis died (from septicaemia) in a mental institution, a martyr for his beliefs. ${ }^{45}$ Reference is also made to the children's nursery rhyme character Chicken Little who believes the sky is falling and dies because he acts on his prediction. ${ }^{46}$ Viewers are shown images from Alfred Hitchcock's film Vertigo, a film which revolves around the theme of being unable to prevent a foreseen event. ${ }^{47}$ Further, Dr Peters, the virologist who releases the virus is involved in his own Kassandra complex. Towards the middle of the film Dr Peters says,

there is very real and very convincing data that the planet cannot survive the excesses of the human race: proliferation of atomic devices, uncontrolled breeding habits, the rape of the environment, the pollution of land, sea, and air. In this context, isn't it obvious that "Chicken Little" represents the sane vision and that Homo Sapiens' motto, "Let's go shopping!" is the cry of the true lunatic? ${ }^{48}$

For Dr Peters his belief that the human race is doomed becomes so essential to his person that it becomes a self-fulfilling prophecy; he believes the human race is doomed and therefore creates the virus and dooms the human race.

\section{Lessons from Kassandra's Dilemma}

Kassandra's tragedy is a lived dilemma for animal and environmental activists in both her visions of the future and her half-life. Like Kassandra seeing the fall of Troy in her vision, activists witness, report and attempt to address the harm being done to the animals and the environment. ${ }^{49}$ Indeed,

$[\mathrm{t}]$ he core of Cassandra's Dilemma is the awareness of our global predicament ... population growth, resource consumption, biodiversity loss, pollution and climate change... ${ }^{50}$

$44 \quad$ Wyklicky H and Skopec M "Ignaz Philipp Semmelweis, The Prophet of Bacteriology" 1983 (4) 5 Infection Control 367 - 370; Best M and Neuhauser D "Ignaz Semmelweis and the birth of infection control" 2004 (13) Quality and Safety in Health Care 233-234; Nuland SB The Doctors' Plague: Germs, Childbed Fever, and the Strange Story of Ignac Semmelweis (WW Norton 2004); Codell Carter K Childbed Fever: A Scientific Biography Of Ignaz Semmelweis (Transaction Publishers New Jersey 2009).

Halliwell-Phillipps JO Popular Rhymes and Nursery Tales: A Sequel to the Nursery Rhymes of England (JR Smith London 1849) 29 -31. Admittedly in this instance Chicken Little is able to convince others of his belief and it is not just his death that results.

48 Peoples and Peoples http://www.imsdb.com/scripts/12-Monkeys.html (Date of use: 4 July 2013). Ethics 63 - 138 67, 95 -96; Shapiro 1994 Society and Animals 152, 153 - 155.

AtKisson 2011 Believing Cassandra. How to be an Optimist in a Pessimist's World 39. AtKisson makes note of some activists he considers to be Kassandra's; activists who struggled with or are still struggling with Kassandra's dilemma such as Rachel Carson author of Silent Spring or activist, politician and Oscar Award winning Al Gore. AtKisson 2011 Believing Cassandra. How to be an Optimist in a Pessimist's World 28 -29, 33 - 39. See also Carson R Silent Spring 
'We have become witnesses to the inflammation of this long-smouldering pathology... ${ }^{51}$ And just as foreknowledge is draining for Kassandra so many activists find that awareness, this foreknowledge, to be emotionally burdensome. ${ }^{52}$

Added to this, just as Kassandra experienced derision and distrust, activists also experience dismissive social reactions. ${ }^{53}$ In the Agamemnon Kassandra is called a mad woman, a sorceress and treated as a beggar and this form of stereotyping and marginalisation is common for activists. ${ }^{54}$ Activists are seen as,

dreadlocked, stinky hippies endlessly fascinated with hemp... too busy chewing on granola and hanging out with the Rainbow Family in some national forest to really wrap [their] heads around how the world works ...skinny and malnourished ... judgmental, moralising nut jobs who drive hybrid cars, endlessly lecture people on sustainability and "carbon footprints" buy shoes made out of recycled tyres and refuse to eat anything that casts a shadow. ${ }^{55}$

Activists are stereotyped as being, 'dour, strict and humourless ... judgemental...find little joy in being human. ${ }^{56}$

To reiterate animal and environmental activists experience the Kassandra complex because they are witnesses to the harm done to animals and the environment (whether directly or indirectly) and they believe that if human behaviour does not change the consequences could be catastrophic. However, like the Trojans no-one wants to hear that the world, as they know it, is going to end, no-one wants to hear that they are vulnerable, mortal; human beings tend to ignore that which we find disagreeable or inconvenient. ${ }^{57}$ Yet, the predictions of global

40 ${ }^{\text {th }}$ anniversary ed (A Mariner Book Houghton Mifflin Company Boston 2002); Gore A Earth in Balance: Ecology and the Human Spirit (Houghton Mifflin Harcourt Publishing Company 1992).

Kovel J The Enemy of Nature (Fernwood Publishing Ltd Nova Scotia 2002) 15.

AtKisson 2011 Believing Cassandra. How to be an Optimist in a Pessimist's World 51, 92.

Shapiro Society and Animals 161; Bryant 2006 Journal of Animal Law and Ethics 63 - 138 115.

Æschylus 1832 Agamemnon 58 -59.

Torres B and Torres J Vegan Freak: Being Vegan in a Non-Vegan World $2^{\text {nd }}$ ed (PM Press Oakland 2010) 6. This quote is referring to vegans. Kroeze IJ "How to eat: vegetarianism, religion and law" 2012 (8) 1 Td The Journal for Transdisciplinary Research in Southern Africa 1 16 10, 11 - 14. In regard to stereotypes surrounding environmental activists see Hutchings $\mathrm{K}$ "Don't Call Me a Treehugger!: Sticks, Stones and Stereotypes in Ecocriticism” 2005 (7) 1 Interdisciplinary Literary Studies 5- 26. Bashir NY "Green" doesn't Always Make Good Impressions: Evaluations of Different Types of Environmentalists (Master of Arts Thesis University of Toronto 2010) 9 - 15. See also Cole M and Morgan K "Vegaphobia: derogatory discourses of veganism and the reproduction of speciesism in the UK national newspapers" 2011 (62) 1 British Journal of Sociology 134 - 153138 -139 for a discussion of negative stereotypes of vegans portrayed in the media; Jo "Stereotypical Vegans" http://www.thisveganlife.org/stereotypical-vegans/ (Date of use: 25 June 2013); Rowley J "Vegan Equality in Law" 2011 (7) Critical Society 4 - 75.

Welch B "The Problem with Environmentalists" http://www.motherearthnews.com/natureand-environment/problem-with-environmentalists.aspx\#axzz2XEHIK2sR (Date of use: 25 June 2013).

AtKisson 2011 Believing Cassandra. How to be an Optimist in a Pessimist's World vii, 79. 
warming and other potential environmental and human threats require that human behaviour towards animals and the environment must change. Thus activists need to escape Kassandra's dilemma and convince others to consider these threats to be real and to act accordingly; and as activists are not cursed by Apollo escaping Kassandra's dilemma must be possible.

However, solving Kassandra's dilemma for animal and environmental activists is no easy feat. Activists have been trying for decades to convince people, governments and countries to act on their beliefs. Mostly this has been unsuccessful. ${ }^{58}$ There have been some successes, such as the measures taken by the Dutch government to reduce industrial pollution or the banning of fur farming in the United Kingdom. ${ }^{59}$ However, if the predictions of activists are right then their message and the information they hold needs to be communicated far more effectively. Merely having knowledge of the threats and how these threats can be prevented is not sufficient for animal and environmental activists. Activists should also know how to communicate this information effectively.

It is here that activists can benefit from a transdisciplinary approach towards animal and environmental issues. After all, an essential aspect of mastering any discipline is knowing how to present your conclusions. ${ }^{60}$ And if a certain discipline does not offer a method through which this can be done effectively (and on a mass scale) then activists must turn to other disciplines which may offer more effective means or may provide insights into how to better present or communicate information.

The disciplines of marketing and communication offer constructive insights for effective activism. ${ }^{61}$ For instance effective branding knowledge and use of this knowledge could benefit activist organisations. ${ }^{62}$ This article will consider the communication theory of innovation

The failure of the Kyoto protocol is just one example. Newell $\mathrm{P}$ "Who 'CoPed' out in Kyoto? An assessment of the third conference of the parties to the framework convention on climate change" 1998 (7) 2 Environmental Politics 153 - 159; Prins G and Rayner S "Time to ditch Kyoto" 2007 (449) Nature 973 - 975.

AtKisson 2011 Believing Cassandra. How to be an Optimist in a Pessimist's World 143 - 162; Fur Farming (Prohibition) Act 2000. The banning of fur farming is seen as both an animal and environmental activism success. See People for the Ethical Treatment of Animals (PETA) "Wool, fur, and leather: hazardous to the environment" http://www.peta.org/issues/animals-used-for-clothing/wool-fur-and-leather-hazardous-tothe-environment.aspx (Date of use: 12 August 2013); The Humane Society of the United States "Toxic fur: the impacts of fur production on the environment and the risks to human health" http://www.humanesociety.org/assets/pdfs/fur/toxic-fur-january-22-2009.pdf (Date of use: 12 August 2012).

60 Kroeze IJ "Legal research methodology and the dream of interdisciplinarity" 2013 (16) 3 Potchefstroom Electronic Law Journal 46.

It is not only the disciplines of marketing and communication that offer insights. Animal and environmental activists can benefit from transdisciplinary research in many other disciplines for instance understanding how people convert religions and belief systems could also be beneficial. See Sachs Norris R "Converting to what? Embodied culture and the adoption of new beliefs" in Buckser A and Glazier SD (eds) The Anthropology of Religious Conversion 171 182.

62 Stride $\mathrm{H}$ andand Lee $\mathrm{S}$ "No logo? No way. Branding in the non-profit sector" 2007 (23) 1 -2 Journal of Marketing Management 107 - 122; Voeth M and Herbst U "The concept of brand personality as an instrument for advanced non-profit branding - an empirical analysis" 2008 (19) 1 Journal of Nonprofit and Public Sector Marketing $71-97$. 
diffusion - how studying the manner in which an innovation gets adopted into a population group; what makes adoption more attractive, what assists quicker adoption and what ensures the adoption is sustained - and how this concept can assist animal and environmental activists in promoting their beliefs. ${ }^{63}$ Innovation diffusion specifically studies how an innovation gets adopted into a culture and considers the qualities of an innovation that ensure successful diffusion. ${ }^{64}$ Thus, in trying to convince people to act on their beliefs innovation diffusion offers animal activists and environmental activists lessons for how to better promote the diffusion of their beliefs.

\section{Innovation Diffusion}

Innovation diffusion looks at the methods by which an innovation is communicated to members of a social group over a period of time. ${ }^{65}$ Diffusion refers to, 'the social process of people talking about the new idea, giving it meaning for themselves, and then adopting'. ${ }^{66}$ Thus innovation diffusion attempts to clarify why, how and at what rate new concepts or technologies spread through social groups. Various studies of innovations and how and why certain innovations have been successful have been performed and resulting from those studies four main elements of innovation diffusion have been identified; namely the innovation, the communication channels used, the time the process takes and the social system or group to which the innovation is being promoted. ${ }^{67}$

\section{The innovation}

Regarding the innovation itself, certain characteristics determine whether or not the innovation will be adopted and how quickly it may be adopted. The first characteristic concerns the relative advantage of the innovation. An innovation which is advantageous because it is of economic benefit, and / or is socially prestigious, and / or is convenient is more likely to be adopted and at a considerably faster rate than a less advantageous innovation. ${ }^{68}$ Despite this, the innovation need not be massively advantageous; there are no set rules for what amounts to a relative advantage, merely the fact that the audience needs to view it as advantageous to them. ${ }^{69}$ The second characteristic concerns compatibility. If an

63 The idea for applying innovation diffusion to activism is not the authors idea, the idea is borrowed (but expanded upon) from the work of Alain AtKisson. See AtKisson 2011 Believing Cassandra. How to be an Optimist in a Pessimist's World 163 - 184.

Robinson L "A summary of diffusion innovations" http://www.enablingchange.com.au /Summary_Diffusion_Theory.pdf (Date of use: 12 August 2013). "The diffusion of innovations perspective" in Weinstein ND (ed.) Taking Care (Cambridge university Press Cambridge 1987) 70 - 94 79. Rogers work is the original and definitive work on the diffusion of innovations; consequently it has been relied on substantially. Rice RE "Diffusion of innovations: theoretical extensions" in Nabi RL and Oliver Mb (eds) The Sage Handbook of Media Processes and Effects (Sage Los Angeles 2009) 489 - 503489.

Rogers EM "Diffusion of preventive innovations" 2002 (27) 6 Addictive Behaviours 989 - 993 992. 
innovation is consistent with the existing values, experience and needs of a consumer then it is likely to be adopted and adopted quickly. ${ }^{70}$ Third, the complexity of the innovation will affect the speed at which it is adopted; if the innovation is easy to use and / or understand then it is likely that the innovation will be adopted quickly. ${ }^{71}$ Forth, an innovation that can be experimented with before adoption is more likely to result in adoption over innovations that are not testable. ${ }^{72}$ When an innovation can be sampled or tested it presents less uncertainty to the consumer and thus is more likely to be adopted after the trial period; to illustrate this characteristic, a consumer is more likely to purchase a vehicle if they are able to test drive it. ${ }^{73}$ Fifth, an innovation that has observable results is more likely to be adopted and adopted quicker than an innovation with uncertain results or with results that take time to evolve. ${ }^{74}$

Normally innovation diffusion is applied to new ideas, practices, technologies, services or products, however, the theory can also be applied to innovations that are preventive. ${ }^{75}$ Preventive innovations are innovations which are adopted in order to prevent some future event from happening. ${ }^{76}$ Because preventive innovations are intended to prevent a future event from happening the results are not immediate (they happen in the future), sometimes the results are intangible and sometimes the innovation is unnecessary (the future event does not happen). ${ }^{77}$ For example, vaccines are given in order to make a person immune to a virus that they may or may not catch in the future. Further, even if a person is vaccinated against a virus they may never know that the vaccine prevented them from becoming infected; the results of this type of preventive innovation are not personally observable. ${ }^{78}$ Thus, unlike nonpreventive innovations the characteristic of observable results is difficult to distinguish with preventive innovations.

In general, preventive innovations are slower to be embraced than non-preventive innovations because usually they do not share the characteristics discussed above that promote fast adoption. ${ }^{79}$ Realising that preventive innovations often do not share these characteristics is important for animal and environmental activists because (without going into depth into the desires of animal and environmental activists) it is probable that the majority of their ideas and practices (and potential products / technologies) fall into the preventive innovation category. For example, taking steps to prevent global warming requires people to adopt preventive ideas and practices (and products) such as going vegan or organic farming or even cycling to work. And as innovation diffusion suggests the benefit of preventive innovations is

Rogers 1995 Diffusion of Innovations 15 - 16.

Rogers 1995 Diffusion of Innovations 16.

Rogers 1995 Diffusion of Innovations 16.

Rogers 1995 Diffusion of Innovations 16.

Rogers 1995 Diffusion of Innovations 16.

Rogers 1987 Taking Care 79-80; Rice 2009 The Sage Handbook of Media Processes and Effects 489.

Rogers 2002 Addictive Behaviours 991.

Rogers 2002 Addictive Behaviours 991.

Although the effect of vaccinations can be monitored through infection rates / morbidity studies etcetera. For instance see Chang $\mathrm{Y}$ et al "Evaluating the impact of human papillomavirus vaccines" 2009 (27) 32 Vaccine 4355 - 4362.

Rogers 1995 Diffusion of Innovations 217. 
not immediate and is difficult to assess. ${ }^{80} \mathrm{~A}$ person cannot see the reduction in carbon emissions that results from adopting a vegan diet or cycling to work instead of driving to work; overall we may only see the benefit of taking steps to prevent global warming in many decades time.

Animal and environmental activists need to take cognisance of the characteristics of successful innovations in regard to their 'preventive' ideas, practices - their innovations. Activists need to consider whether they are highlighting the advantages of their innovations, whether their innovation is compatible with the market, how easily understandable the innovation is, whether it is testable and whether the market can see the results. And if the innovation does not meet these characteristics activists need to consider how this can be remedied.

Considering the vegan lifestyle as an example of an animal activist or environmental activist innovation it is easy to see that the lifestyle does not share many of the characteristics of successful innovations. ${ }^{81}$ The vegan lifestyle is not obviously advantageous to the consumer and rarely is it compatible with a consumer's values and experiences. ${ }^{82}$ Further following a vegan lifestyle is complex; a consumer should understand the philosophical / ethical / moral / practical / environmental reasons for it and the consumer has to understand nutritional requirements for a healthy vegan diet. ${ }^{83}$ Moreover, whilst it is easy to try out or experiment with a vegan lifestyle it is incredibly difficult to see the results of the lifestyle - whether the results are beneficial to animals, the environment or even to the individual's health. ${ }^{84}$ Thus expecting a vegan lifestyle to be adopted en masse and to be adopted quickly is unreasonable.

Knowing this, people who promote a vegan diet should be aware of these issues and adjust their promotion to account for such. For instance, instead of promoting veganism on moral or ethical grounds an activist may wish to focus on the health advantages of veganism (ensuring that there is adequate information on how to ensure a healthy vegan diet). Thus instead of suggesting that animals are sentient creatures with rights which may not meld with a potential adopter's values and beliefs, an animal activist may wish to highlight how the

$80 \quad$ Rogers 1987 Taking Care 80.

81 For the environmental damage caused by eating meat see Steinfeld et al Livestock's Long Shadow 4- 6; $79-114,125-169 ; 181$ - 215.

For compatibility issues see Kroeze 2012 Td $1-16$; Berry W "The pleasures of eating" in Curtin DW and Heldke LM (eds) Cooking, eating, thinking: transformative philosophies of food (Indiana University Press 1992) 374-379. It should be noted that there is a significant difference between a vegan lifestyle and a vegan diet. "A vegan is someone who tries to live without exploiting animals, for the benefit of animals, people and the planet. Vegans eat a plant-based diet, with nothing coming from animals- no meat, eggs, milk or honey, for example. A vegan lifestyle also avoids leather, wool, silk and other animal products for clothing or any other purpose." The Vegan Society "Why vegan?" http://www.vegansociety.com/become-a-vegan/why.aspx (Date of use: 14 August 2013).

See Walsh S Plant-Based Nutrition and Health (Vegan Society Limited 2007) for a source on how to eat a healthy, balanced vegan diet. 1627S - 1633S; Key TJ, Davey GK and Appelby PN "Health benefits of a vegetarian diet" 1999 (58) 2 Proceedings of the Nutrition Society 271 - 275; Sabate J "The contribution of vegetarian diets to health and disease: a paradigm shift" 2003 (78) 3 American Journal of Clinical Nutrition 502S - 507S. 
vegan diet contributes to good heath which may be conducive to the potential adopter's health concerns. Or, instead of merely focussing on the vegan diet, animal activists could promote other aspects of the vegan lifestyle such as wearing leather substitutes, or using household products and beauty products that do not contain animal ingredients and which were not tested on animals. Sometimes changing the context of a preventative innovation can encourage its adoption. ${ }^{85}$

\section{Communication}

Innovation diffusion requires effective communication, and this is incredibly important for animal and environmental activists. In order to escape Kassandra's dilemma activists need to communicate with their audience effectively.

Communication of an innovation happens through two mediums; the mass media and interpersonal communications and social networks. ${ }^{86}$ Mass media plays an important role in conveying information and creating awareness about an innovation. However studies of preventive innovations have shown that mass media does not convince people to adopt a preventive innovation; it merely conveys knowledge and creates awareness. ${ }^{87}$ An innovation is more likely to be adopted if the innovation is communicated to the potential adoptee through a peer or near-peer connection and if the communicator has successfully adopted the innovation themselves. ${ }^{88}$ Thus preventive innovations are better communicated through interpersonal communication and social networks; especially when the communicator and the audience are homophilous. ${ }^{89}$ Individuals are more likely to communicate better and more frequently if they share similar attributes such as beliefs and education. ${ }^{90}$ Further a communicators standing within a social network will greatly influence the speed and extent of adoption of the innovation. ${ }^{91}$ Having said that a person will not adopt a preventive innovation merely because someone with power has told them to do so, the person conveying the information must be credible. ${ }^{92}$ Thus a person is more likely to adopt a vegan lifestyle when they hear about it from a high standing member of their community / organisation such as a church official or teacher provided that person also follows a vegan lifestyle.

Thus animal and environmental activists need to be careful about who they choose to represent their cause and to which audience. 'The fate of innovation, its content but also its chances of success, rest entirely on the choice of the representatives or spokespersons who will

Rogers 1987 Taking Care 93.

Rice 2009 The Sage Handbook of Media Processes and Effects 492.

Rogers 1987 Taking Care 93; Rice 2009 The Sage Handbook of Media Processes and Effects 492.

Rogers 2002 Addictive Behaviours 993, 990; Robinson
http://www.enablingchange.com.au/Summary_Diffusion_Theory.pdf (Date of use: 12 August 2013).

Individuals are homophilous when they share attributes such as beliefs, education or social status. Lazerfeld PF and Merton RK "Friendship as social process: a substantive and methodological analysis" in Berger M, Abel T and Page CH (eds) Freedom and Control in Modern Society (Octagon New York 1964) 18 -66; Rogers 1995 Diffusion of Innovations 18 19.

Rogers 1995 Diffusion of Innovations 286.

Rice 2009 The Sage Handbook of Media Processes and Effects 493.

Rogers 1987 Taking Care 93. 
interact, negotiate to give shape to the project and to transform it until a market is built'. ${ }^{93}$ The spokesperson must be credible to the audience otherwise the innovation / organisation is deemed unreliable. ${ }^{94}$ Activists even need to consider factors such as the ethnicity of the spokesperson in relation to the audience and even the accent of the speaker. ${ }^{95}$ Further, activist organisations need to ensure that the people representing their organisation (and consequently their beliefs) are adequately trained and adequately prepared to meet nonconverts. $^{96}$

\section{Time}

Time is also an important element of the innovation diffusion process. Time applies to the innovation decision process (this is the period it takes from an individual becoming aware of the innovation to deciding whether to adopt or reject the innovation), as to whether an individual adopts the innovation quickly or slowly (as compared to others) and to the rate of adoption (how many people in a social group adopt the innovation within a specific time period). ${ }^{97}$

The time factor is highly dependent on each situation and will be affected by who is doing the communication, of what and to whom (individual or group). ${ }^{98}$ An individual will typically go through a five stage process in deciding whether or not to adopt the innovation; namely knowledge of the innovation (becoming aware of the innovation, first exposure to the innovation), persuasion (gaining knowledge / opinion), deciding whether or not to adopt (the individual will weigh up the advantages and the disadvantages), implementing the innovation (trial stage; individual tests out the innovation, gains more knowledge regarding innovation) and confirming their decision (individual will either stick with their decision to implement it or reject the innovation). ${ }^{99}$

Having said this it is essential for animal and environmental activists to remember that preventive innovations are generally adopted slowly and that the results are not readily or easily observable. Thus activists should not become despondent or think they have failed when they do not see immediate results.

\section{The social system or group}

'Diffusion occurs within a social system. ${ }^{100}$ Various factors effect diffusion within a specific social system. First the structure of the social system can greatly influence whether or not an

Akrich M, Callon M and Latour B "The key to success in innovation Part II: the art of choosing good spokespersons" 2002 (6) 2 International Journal of Innovation Management 207 $-225217$.

Arpan LM "When in Rome? The Effects of Spokesperson Ethnicity on Audience Evaluation of Crisis Communication” 2002 (39) Journal of Business Communication 314 - 339315.

Arpan 2002 Journal of Business Communication 316-318, 319.

Kaner EFS et al "A RCT of three training and support strategies to encourage implementation of screening and brief alcohol intervention by general practitioners" 1999 (49)

British Journal of General Practice 699 - 703701.

Rogers 1995 Diffusion of Innovations 20.

Rice 2009 The Sage Handbook of Media Processes and Effects 498.

Rogers 1995 Diffusion of Innovations 162.

Rogers 1995 Diffusion of Innovations 24. 
innovation is adopted and how quickly it is adopted. ${ }^{101}$ Some social structures work as a collective unit and others do not thus an innovation may be adopted by an individual member within a social system or by the entire system (through a collective decision or by an authoritarian decision). ${ }^{102}$ Further the social system is affected by, 'economics, network cooperation, power relations, governmental policies, competition / cooperation, and standardization...,

Diffusion is particularly affected by the communication within a specific social system or group and the behaviour patterns within the group. ${ }^{104}$ As previously stated innovation diffusion is more likely to occur when parties are homophilous however homophily requirements limit the social network in which an innovation can diffuse. ${ }^{105}$ Thus the structure of a social system can aid diffusion because people within the system or within a clique of the system are likely homophilous. ${ }^{106}$ However, as is apparent from the words, homophilous communication only allows for communication among people who share similar beliefs and values. Thus homophilous communication promotes horizontal diffusion; it does not support vertical diffusion to audiences that do not share similar values and beliefs. Thus in order to promote greater diffusion (to reach social networks that do not share the same values and beliefs as the innovator) some herterophilous communication is required and in this regard the structure of the social system may be limiting. ${ }^{107}$ Often, the promotional campaigns used by the People for the Ethical Treatment of Animals do not consider the heterophilousness of their audience, and result in antagonising and alienating certain population segments. ${ }^{108}$

Thus considering the social structure of the network and the degree of homophilousness or heterophilousness within the organisation should be considered. Generally heterophilous networks are more inclined towards communicators who are of a higher socioeconomic status; who are more formally educated than the network; who have mass media exposure; who are worldlier; who are well connected and who are adopters of the innovation. ${ }^{109}$

\section{Recommendations}

As previously stated, the majority of animal and environmental activist innovations are preventive; they exist in order to prevent a future event from happening. And, as also previously stated, preventive innovations are more difficult to promote and if they are adopted

\footnotetext{
$101 \quad$ Rogers 1995 Diffusion of Innovations 24.

102 Rogers 1995 Diffusion of Innovations 28.

103 Rice 2009 The Sage Handbook of Media Processes and Effects 493.

104 Rogers 1995 Diffusion of Innovations 25 - 26. See Kroeze 2012 Td 1 - 16 in regard to reasons why a specific group may choose not to follow a vegan lifestyle.

$105 \quad$ Rogers 1995 Diffusion of Innovations 288.

106 Rogers 1995 Diffusion of Innovations 24 - 25.

107 Rogers 1995 Diffusion of Innovations 24 - 25; 288.

108 For an argument suggesting the PETA campaigns exclude overweight people and people of colour see Kociẹda A "The PETA Complex: On post-feminist activism, gender, and veganism" http://feministcurrent.com/7375/the-peta-complex-on-post-feminist-activismgender-and-veganism/ (Date of use: 2 August 2013).

109 Rogers 1995 Diffusion of Innovations 289.
} 
they are adopted at a slower rate than non-preventive innovations. However, some strategies are suggested for promoting the adoption and to speed up the adoption of preventive innovations. To begin with, it is important for the relative advantages of the preventive innovation to be stressed and if necessary the attributes should be changed or relabelled. ${ }^{110} \mathrm{By}$ doing this you can change an individual's perception of the innovation that is promoting veganism for health reasons or promoting it because it is inevitable. Next, preventive innovations should be championed by carefully selected spokespeople. ${ }^{111}$ Further, people who have standing within a social system or organization should be targeted as they have access to social networks and can act as change agents within those networks. ${ }^{112}$ And finally use peer networks to diffuse the innovation because once a critical mass (a certain number of people) adopts an innovation it becomes self-sustaining, in other words individuals adopt the innovation without the need of promoting it. ${ }^{113}$

\section{Conclusions}

Assuming that the predictions of animal and environmental activists are correct, for instance if global warming and climate change are real threats to human existence or if the transmission of a virus from animals to humans could result in a biological genocide then everyone needs to act on those predictions and take preventive steps, such as going vegan, to prevent them from happening. Consequently, it is essential that animal and environmental 'Kassandras' escape her dilemma and convince people to believe and act on their prophecies.

Whether or not using lessons learnt from innovation diffusion will result in activists breaking free of Kassandra's dilemma is open to discussion. However, what is essential is that the key to escaping Kassandra's curse will not be found in repeating tried and tested methods. Instead animal activists and environmental activists need to explore disciplines beyond their traditional knowledge areas. The answer for activists may lie in transdisciplinary research and in applying the lessons learnt from such research. Thus activists need to expand their boundaries, expand their expertise to better advocate for their beliefs.

110 Rogers 2002 Addictive Behaviours 993, 992. Some scientists suggest that the majority of the world's population will adopt a vegetarian diet by 2050 . See Vidal J "Food shortages could force world into vegetarianism, warn scientists" http://www.theguardian.com/globaldevelopment/2012/aug/26/food-shortages-world-vegetarianism (Date of Use: 13 August 2013).

$111 \quad$ Rogers 2002 Addictive Behaviours 992.

112 Rogers 1995 Diffusion of Innovations 326. For more recommendations see Rogers 2002 Addictive Behaviours 992.

113 Rogers 2002 Addictive Behaviours 992; Rogers 1995 Diffusion of Innovations 313. 